\title{
Radioimmunotherapy consolidation and rituximab maintenance in the initial treatment of follicular lymphoma
}

\author{
Franz Buchegger ${ }^{1,2^{*}}$ and Oliver W Press ${ }^{3,4}$
}

\begin{abstract}
Several reports have documented similar efficacies and tolerable toxicities of radioimmunotherapy (RIT) consolidation and rituximab maintenance after initial R-chemotherapy of follicular lymphoma. The relative merits of these two interventions are currently under discussion. We now raise the question whether both RIT consolidation and rituximab maintenance should be used together aiming to augment the results achievable with Rchemotherapy.
\end{abstract}

Keywords: Radioimmunotherapy consolidation, Rituximab maintenance, Follicular lymphoma

\section{Letter to the Editor}

The recent review of T.M. Illidge on radioimmunotherapy (RIT) of lymphoma highlighted the inherent potential of this particular treatment [1]. While convinced of the efficacy of RIT he regretted the low implementation of RIT in current clinical practice.

We would like to elaborate further on the biological agents that have shown efficacy in treatment of follicular lymphoma. In a small series of relapsed indolent lymphoma patients treated in Switzerland with 131I-tositumomab (Bexxar ${ }^{\circledR}$, GlaxoSmithKline, Brentford, UK), we experienced several long-lasting complete remissions with six of 12 patients (50\%) reaching 10 -years progression free survival without any further treatment [2]. Similar 10-year progression-free survivals after ${ }^{131} \mathrm{I}$-tositumomab in relapse have been reported by another group, though at a somewhat lower rate [3]. The Southwest Oncology Group (SWOG) has demonstrated that $67 \%$ of follicular lymphoma patients remained progression free more than 5 years after consolidation of CHOP chemotherapy with ${ }^{131}$ I-tositumomab [4]. Yet, another group has communicated a $50 \%$ complete response $(\mathrm{CR})$ rate after 10 years following an initial treatment using abbreviated fludarabine combined with

\footnotetext{
* Correspondence: Franz.Buchegger@chuv.ch

'Department of Nuclear Medicine, University Hospital of Lausanne, Lausanne, Switzerland

Full list of author information is available at the end of the article
}

${ }^{131}$ I-tositumomab [5]. A high number of persistent CRs at 5 to 6 years was also reported for ${ }^{131}$ I-tositumomab alone in the initial treatment of follicular lymphoma [6].

High efficacy of RIT with 90Y-ibritumomab has also been reported repeatedly including a report demonstrating 5 -year relapse free survival in about $20 \%$ of relapsed patients [7]; however, 10-year observations are currently not available to us.

${ }^{90}$ Y-ibritumomab (Zevalin ${ }^{\circledR}$, Spectrum Pharmaceuticals, Henderson, NV, USA) is the only RIT currently approved in Europe, and its successful use in consolidation treatment following chemotherapy has been well documented [8]. On the other hand, rituximab (Mabthera $^{\circledR}$, Rituxan ${ }^{\circledR}$, Roche Ltd., Genentech, Basel, Switzerland) maintenance treatment after R-chemotherapy was recently shown to improve the relapse-free survival in a large phase III study [9].

Several reports have documented similar efficacies of RIT consolidation and rituximab maintenance, though these approaches have not been formally tested in a randomized trial. Both complementary treatments have moderate and/or transient side effects. The mode of action of these two added therapies, however, are different. Rituximab maintenance is an immunotherapy while ${ }^{131}$ I-tositumomab and ${ }^{90} \mathrm{Y}$-ibritumomab are targeted radiation therapies administered in combination with two injections of moderate amounts of unlabeled antibody. The latter approach is supported by long-standing

\section{SpringerOpen $^{\circ}$}

(C) 2011 Buchegger and Press; licensee Springer. This is an Open Access article distributed under the terms of the Creative Commons Attribution License (http://creativecommons.org/licenses/by/2.0), which permits unrestricted use, distribution, and reproduction in any medium, provided the original work is properly cited. 
evidence showing that radiotherapy may occasionally be curative when used as initial treatment for localized follicular lymphoma [10]. We envision a similar potential for RIT given in advanced disease either alone or combined with chemotherapy, as initial treatment or in relapse $[2,3,5]$.

The 10-year progression-free survival as observed after ${ }^{131}$ I-tositumomab either alone or combined with chemotherapy, upfront or at relapse of follicular lymphoma, appears to be an important milestone. It is anticipated that this approach might afford a low recurrence rate in subsequent years, analogous to that observed after external beam radiotherapy [10]. The low-energy electrons emitted by ${ }^{131}$ I are also prone to eradicate microscopic disease, as has been shown by others and us in RIT of small-sized lung or liver metastatic disease, respectively $[11,12]$.

Further improved biological efficacy in NHL might be achieved by combining anti-CD20 rituximab treatment with other antibodies directed against other antigens, such as anti-CD22 or anti-CD40, utilizing humanized antibodies, or novel anti-CD20 antibodies with modified Fc domains providing increased affinity for Fc receptors and improved effector functions as discussed previously $[13,14]$.

In current practice, rituximab has appropriately assumed a dominant position in treatment of lymphoma both in combination with chemotherapy and as maintenance [9]. We now raise the question whether both rituximab and RIT should be used together as complementary methods to augment the results achievable with chemotherapy and whether this combined modality approach might afford additive or synergistic benefit. This strategy might also allow reducing chemotherapy as has been shown with abbreviated fludarabine combined with RIT [5]. An attenuated R-CHOP as recently described for elderly patients could possibly be envisaged in such a triple therapy approach [15].

We acknowledge that there is currently little published data demonstrating the efficacy of anti-CD20 RIT following rituximab-containing induction chemotherapy regimens. This information gap will be partially remedied by a phase II study investigating this combined approach that has recently been piloted by SWOG in the NCT00770224 trial, which is assessing the toxicity and efficacy of R-CHOP induction chemotherapy followed by ${ }^{131}$ I-tositumomab consolidation and 4 years of rituximab maintenance. This study will assess the potential impact of administering rituximab anti-CD20 antibody with CHOP prior to anti-CD20 RIT [16], though in this trial rituximab was deliberately omitted from the last two cycles of $\mathrm{CHOP}$ chemotherapy, to minimize blocking of CD20 antigenic sites prior to RIT. If favorable results are achieved in this phase II trial, a phase III randomized study comparing this "triple" approach with maintenance rituximab alone or consolidation RIT alone following induction with R-chemotherapy would be warranted.

\section{List of abbreviations}

$R I T$ : radioimmunotherapy; $R$-chemotherapy :rituximab and chemotherapy; $R$ CHOP: combined rituximab, cyclophosphamide, doxorubicin, vincristine, and prednisone; SWOG (US): Southwest Oncology Group.

\section{Author details}

'Department of Nuclear Medicine, University Hospital of Lausanne, Lausanne, Switzerland ${ }^{2}$ Department of Nuclear Medicine, University Hospitals of Geneva, Geneva, Switzerland ${ }^{3}$ Fred Hutchinson Cancer Research Center, Seattle, WA98109, USA ${ }^{4}$ Division of Oncology, Department of Medicine, University of Washington, Seattle, WA98195, USA

\section{Authors' contributions}

Both authors express in this letter their opinion, edited and corrected this letter and approved its final version.

\section{Competing interests}

OWP declares a compensated consultant and advisory role and having received honoraria from Hoffmann-LaRoche/Genentech and Spectrum Pharmaceuticals as well as having received research funding from Hoffmann-LaRoche/Genentech. FB has no competing interest to declare.

Received: 17 May 2011 Accepted: 20 June 2011 Published: 20 June 2011

\section{References}

1. Illidge TM: Radioimmunotherapy of lymphoma: a treatment approach ahead of its time or past its sell-by date? J Clin Oncol 2010, 28:2944-2946.

2. Buchegger F, Antonescu C, Helg C, Kosinski M, Prior JO, Bischof Delaloye $A B$, Press $O W$, Ketterer $N$ : Six of 12 relapsed refractory indolent lymphoma patients treated 10 years ago with 131 l-tositumomab remain in complete remission. J Nucl Med 2011, 52:896-900.

3. Kaminski MS, Zelenetz AD, Press OW, Saleh MN, Leonard JP, Fehrenbacher L, Lister TA, Horner TJ, Williams VC, Lin TS, Vleisides C, Knox SJ, Wahl RL, Vose MJ: Tositumomab and I 131 Tositumomab achieves complete remissions lasting $>10$ years in patients with chemotherapy-refractory low grade and transformed B-cell lymphomas. Blood 2010, 116:Abstract 3960.

4. Press OW, Unger JM, Braziel RM, Maloney DG, Miller TP, LeBlanc M, Fisher Rl: Phase II trial of CHOP chemotherapy followed by tositumomab/iodine I-131 tositumomab for previously untreated follicular non-Hodgkin's lymphoma: five-year follow-up of Southwest Oncology Group Protocol S9911. J Clin Oncol 2006, 24:4143-4149.

5. Martin P, Coleman M, Furman RR, Vallabhajosula S, Kim DS, Edelstein A, Morrison J, Elstrom R, Ruan J, Goldsmith SJ, Leonard JP: Fludarabine plus I131 tositumomab as initial treatment for follicular lymphoma: half of patients in remission at over 10 years median followup. Blood 2010, 116: Abstract 1785

6. Kaminski MS, Tuck M, Estes J, Kolstad A, Ross CW, Zasadny K, Regan D, Kison P, Fisher S, Kroll S, Wahl RL: 131I-tositumomab therapy as initial treatment for follicular lymphoma. N Engl J Med 2005, 352:441-449.

7. Witzig TE, Molina A, Gordon LI, Emmanouilides C, Schilder RJ, Flinn IW, Darif M, Macklis R, Vo K, Wiseman GA: Long-term responses in patients with recurring or refractory B-cell non-Hodgkin lymphoma treated with yttrium 90 ibritumomab tiuxetan. Cancer 2007, 109:1804-1810.

8. Morschhauser F, Radford J, Van Hoof A, Vitolo U, Soubeyran P, Tilly H, Huijgens PC, Kolstad A, d'Amore F, Gonzalez GM, Petrini M, Sebban C, Zinzani PL, van Oers MHJ, van Putten W, Bischof-Delaloye A, Rohatiner A, Salles G, Kuhlmann J, Hagenbeek A: Phase III trial of consolidation therapy with yttrium-90-ibritumomab tiuxetan compared with no additional therapy after first remission in advanced follicular lymphoma. J Clin Oncol 2008, 26:5156-5164.

9. Salles G, Seymour JF, Offner F, López-Guillermo A, Belada D, Xerri L, Feugier P, Bouabdallah R, Catalano JV, Brice P, Caballero D, Haioun C, Pedersen LM, Delmer A, Simpson D, Leppa S, Soubeyran P, Hagenbeek A, 
Casasnovas $\mathrm{O}$, Intragumtornchai T, Fermé $\mathrm{C}$, da Silva MG, Sebban C, Lister A, Estell JA, Milone G, Sonet A, Mendila M, Coiffier B, Tilly H: Rituximab maintenance for 2 years in patients with high tumour burden follicular lymphoma responding to rituximab plus chemotherapy (PRIMA): a phase 3, randomised controlled trial. Lancet 2011, 377:42-51.

10. Mac Manus MP, Hoppe RT: Is radiotherapy curative for stage I and II lowgrade follicular lymphoma? Results of a long-term follow-up study of patients treated at Stanford University. J Clin Oncol 1996, 14:1282-1290.

11. Sharkey RM, Weadock KS, Natale A, Haywood L, Aninipot R, Blumenthal RD, Goldenberg DM: Successful radioimmunotherapy for lung metastasis of human colonic cancer in nude mice. J Natl Cancer Inst 1991, 83:627-632.

12. Vogel CA, Galmiche MC, Buchegger F: Radioimmunotherapy and fractionated radiotherapy of human colon cancer liver metastases in nude mice. Cancer Res 1997, 57:447-453.

13. Sharkey RM, Karacay H, Goldenberg DM: Improving the treatment of nonHodgkin lymphoma with antibody-targeted radionuclides. Cancer 2010, 116:1134-1145.

14. Buchegger F, Press OW, Delaloye Bischof A, Ketterer N: Radiolabeled and native antibodies and the prospect of cure of follicular lymphoma. Oncologist 2008, 13:657-667.

15. Peyrade F, Jardin F, Thieblemont C, Thyss A, Emile JF, Castaigne S, Coiffier B, Haioun C, Bologna S, Fitoussi O, Lepeu G, Fruchart C, Bordessoule D, Blanc M, Delarue R, Janvier M, Salles B, André M, Fournier M, Gaulard P, Tilly $\mathrm{H}$, for the Groupe d'Etude des Lymphomes de l'Adulte (GELA) investigators: Attenuated immunochemotherapy regimen (R-miniCHOP) in elderly patients older than 80 years with diffuse large B-cell lymphoma: a multicentre, single-arm, phase 2 trial. Lancet Oncol 2011, 12:460-468.

16. Gopal AK, Press OW, Wilbur SM, Maloney DG, Pagel JM: Rituximab blocks binding of radiolabeled anti-CD20 antibodies (Ab) but not radiolabeled anti-CD45 Ab. Blood 2008, 112:830-835.

doi:10.1186/2191-219X-1-7

Cite this article as: Buchegger and Press: Radioimmunotherapy consolidation and rituximab maintenance in the initial treatment of follicular lymphoma. EJNMMI Research 2011 1:7.

\section{Submit your manuscript to a SpringerOpen ${ }^{\circ}$ journal and benefit from:}

- Convenient online submission

- Rigorous peer review

- Immediate publication on acceptance

- Open access: articles freely available online

- High visibility within the field

- Retaining the copyright to your article

Submit your next manuscript at $\gg$ springeropen.com 